\title{
Article
}

\section{The Framework of Technical Evaluation Indicators for Constructing Low-Carbon Communities in China}

\author{
Yifei Bai ${ }^{1}$, Weirong Zhang ${ }^{1, *(\mathbb{D},}$, Xiu Yang ${ }^{2}$, Shen Wei ${ }^{3} \mathbb{C}$ and Yang Yu ${ }^{4}$ \\ 1 Key Laboratory of Green Built Environment and Energy Efficient Technology, \\ Beijing University of Technology, Beijing 100124, China; baiyifei@emails.bjut.edu.cn \\ 2 Institute of Climate Change and Sustainable Development, Tsinghua University, Beijing 100080, China; \\ yangxiuthu@tsinghua.edu.cn \\ 3 The Bartlett School of Construction and Project Management, University College London (UCL), \\ 1-19 Torrington Place, London WC1E 7HB, UK; shen.wei@ucl.ac.uk \\ 4 School of Architecture, Xi'an University of Architecture and Technology, Xi'an 710055, China; \\ yuyang@xauat.edu.cn \\ * Correspondence: zhangwr@bjut.edu.cn
}

check for updates

Citation: Bai, Y.; Zhang, W.; Yang, X.; Wei, S.; Yu, Y. The Framework of Technical Evaluation Indicators for Constructing Low-Carbon Communities in China. Buildings 2021, 11, 479. https://doi.org/ 10.3390/buildings11100479

Academic Editor: Audrius Banaitis

Received: 31 July 2021

Accepted: 11 October 2021

Published: 15 October 202

Publisher's Note: MDPI stays neutral with regard to jurisdictional claims in published maps and institutional affiliations.

Copyright: (c) 2021 by the authors. Licensee MDPI, Basel, Switzerland. This article is an open access article distributed under the terms and conditions of the Creative Commons Attribution (CC BY) license (https:// creativecommons.org/licenses/by/ $4.0 /)$.

\begin{abstract}
In recent years, in order to promote the construction of low-carbon communities (LCCs) in China, many scholars have proposed an evaluation indicator system of LCC. The existing indicator systems are mostly established from the macro perspective of environmental impact and resource conservation, but few are from the micro technical perspective. Thus, the aim of this study is to construct a micro technical evaluation indicator system for LCCs. Firstly, the index system was divided into three categories: low-carbon building, low-carbon transportation, and low-carbon environment. Then, the technical indicators were selected through empirical analysis. The indicator weights were assigned by the improved analytic hierarchy process (AHP) and the multi-level fuzzy comprehensive evaluation method was used as the evaluation method of the indicators. Finally, in order to examine the practicality of the indicator system, two typical communities in Tianjin and Shanghai were selected as case studies. The results showed that the indicator system gave a reasonable low-carbon level for the two communities, which was in line with the actual low-carbon construction status of each community. In addition, the evaluation results pointed out that the lowcarbon community (LCC) in Tianjin needs to further strengthen the construction of the low-carbon environment, including community compactness, rainwater collection and utilization, and waste recycling. For the LCC in Shanghai, it was pointed out that the construction of the low-carbon building and low-carbon transportation needs to be strengthened. The indicator system can be used as a tool for urban planning and construction personnel to evaluate the construction progress and low-carbon degree of LCC.
\end{abstract}

Keywords: low-carbon community; technical indicators; improved analytic hierarchy process; multi-level fuzzy comprehensive evaluation method

\section{Introduction}

In recent decades, with the rapid development of different countries, global carbon emissions have increased rapidly [1,2]. The increasing carbon emissions have increased the pressure on natural systems and resources, which directly leading to global climate change and the deterioration of the ecological environment [3]. The rapid urbanization process is one of the main factors leading to the increase in carbon emissions. Urban areas contribute more than $70 \%$ of the total energy demand and a corresponding proportion of the world's $\mathrm{CO}_{2}$ emissions [4]. As the most basic unit in urban construction, the urban community is not only the main space carrier of human life, entertainment, and industrial production, but also the main carrier of urban carbon emissions $[5,6]$. Low carbon research at the community level is the foothold of the implementation of low-carbon 
urban planning strategies, and also plays a role in improving the low-carbon technology of single buildings $[7,8]$. Therefore, how to build an LCC has become a research hotspot in many countries.

As the largest developing country and the second largest economy in the world, China's rapid urbanization process consumes a lot of energy and produces a lot of carbon emissions, accounting for about a quarter of the world's total carbon emissions in the past five years [9]. The research on LCC in China is of great significance for both China and the world to reduce carbon emissions. At present, the research on LCC is mainly divided into quantitative and qualitative evaluation. In terms of quantitative evaluation of LCCs, song et al. [10] proposed an accounting framework for community carbon emissions based on the method of life cycle assessment (LCA), including direct fossil fuel combustion emissions, energy purchase (electricity, heat, and water) emissions, and supply chain emissions reflected in commodity consumption, which quantified the scale and mitigation potential of community carbon emissions. Yıldırım et al. [11] collected data on energy use, land demand, raw material consumption, and carbon emissions of communities, and quantified the environmental impact of different wastewater treatment options using LCA. Lin et al. [12] established a comprehensive accounting model based on the guidelines of the Intergovernmental Panel on Climate Change (IPCC) and the LCA method to more comprehensively and accurately quantify the carbon emissions and carbon sinks of communities. Although quantitative evaluation can give more intuitive results, its time and data requirements, complexity, and cost-benefit ratio have great uncertainty. There are still some difficulties in the application of quantitative evaluation in the actual LCC planning. The qualitative evaluation of LCC has the characteristics of simplicity, fewer data, and strong comprehensiveness, which is welcomed by scholars and urban planners. The United Kingdom has proposed a BREEAM community evaluation system for the construction of sustainable communities. The United States established the LEED-ND system to evaluate the sustainable development of community planning and construction. Japan has established the CASBEE-UD system to guide the ecological and green construction of communities $[13,14]$. Most of these evaluation index systems are built from the perspective of ecology, livability, and sustainability, and rarely from the perspective of low carbon. In terms of the construction of LCC evaluation indicators, the Chinese National Development and Reform Commission issued the Pilot Low-Carbon Communities Construction Guide, which defines the construction objectives, contents, and standards of China's LCCs. From the perspective of "carbon source control" and "carbon sink expansion", Wang et al. [15] established six evaluation indicators of LCCs. Based on the actual situation of urban LCCs in Guangdong Province, Xie et al. [16] established an evaluation system. Based on the theory and practice of LCC, Luo and Zhan [17] constructed the evaluation index of renewable energy utilization and green vegetation. Jiang and Guo [18] developed the evaluation index of LCC from the planning experience of LCC, such as energy conservation and creating a suitable ecological environment. Moghadam et al. [19] developed a new multicriteria spatial decision support system, which established the relationship between the energy of urban communities and the economic, social, technical, and environmental performance of transformation interventions, and provided meaningful community energy transformation schemes. However, most of the above LCC evaluation indicators are established from the macro perspective of reducing environmental impact and saving resources, and there are no evaluation indicators established from the micro technical perspective. Macroscopic evaluation indices can grasp the construction direction of LCCs, while technical evaluation indices are specific measures to reduce carbon emissions in each construction direction. Therefore, it is necessary to establish a technical evaluation index system of LCCs. The purpose of building the indicator system is to provide a useful tool for community planners to evaluate the low-carbon degree of a low-carbon community in the planning and construction stage or operation stage, and point out the low-carbon technologies that need to be further strengthened in a community. 
In this study, firstly, combined with the previous construction contents of LCCs and the construction management departments of Chinese communities, the technical indicators of LCCs were divided into three categories: low-carbon building, low-carbon transportation, and low-carbon environment. Based on the examples of the LCC evaluation index system at home and abroad, and combined with the actual situation of China, a technical index pool was established, and the appropriate indicators were selected through empirical analysis. Then, the weight of the selected index was calculated by using the improved AHP, and the multi-level fuzzy comprehensive evaluation method was selected as the evaluation method of the index. Finally, two typical communities in Tianjin and Shanghai were selected to verify the practicality of the index system. The indicator system constructed in this study gave a reasonable low-carbon level for the two communities, which was in line with the actual low-carbon construction status of each community. The indicator system can not only evaluate the degree of low carbon in a community, but also indicate the aspects in which a community needs to strengthen the use of low-carbon technology, which can be used as a tool for community planning and construction personnel to evaluate the construction progress and degree of low carbon in LCCs.

\section{Methodology}

In the process of constructing an indicator system, the selection of the indicator and the assignment of the indicator weight are the two most important steps [20,21]. In terms of the selection of indicators, some scholars use frequency analysis; that is, the indicators with higher frequency are used preferentially [22,23]. However, in this method, the important indicators with lower frequency are often ignored. Lu et al. [24] established some sustainable indicator systems according to local regional geographical characteristics and the ecological environment, drawing lessons from the existing LCC evaluation indicator system, which are often not systematic. In this study, based on the current LCC evaluation system and famous LCC cases (including BedZED in the U.K., the Vauban District in Germany, the Hammarby community in Sweden, Beder in Denmark, and the Changxindian community in Beijing [25]), an indicator pool was established, and then the technical indicators were selected through empirical analysis to build a comprehensive technical indicator system for constructing LCCs [26]. For the assignment of indicator weight, the most commonly used method is the analytic hierarchy process (AHP) [27,28]. However, the traditional AHP is suitable for the comparative judgment of a small number of indicators, which is difficult to apply to the more complex evaluation indicators of LCCs. Additionally, the consistency test of the traditional AHP comparison matrix is complicated $[29,30]$. In this study, the improved AHP overcame the shortcomings of the traditional AHP, and the weight of each indicator could be calculated quickly and conveniently [31,32]. Then, for the index system, a suitable comprehensive evaluation method needs to be selected. Currently, the more commonly used comprehensive evaluation methods include the Grey Correlation Method, Artificial Neural Network Method, Technique for Order Preference by Similarity to an Ideal Solution (TOPSIS) Method, and Fuzzy Comprehensive Evaluation Method. The Grey Correlation Method is applicable to a large number of evaluation indicators, and some indicators have the characteristics of correlation or repetition [33,34]. The Artificial Neural Network Method is more suitable for the case of a large amount of data [35]. Because the TOPSIS Method has no definite method for the transformation of neutral indicators, the final result of comprehensive evaluation is not very accurate [36,37]. The Fuzzy Comprehensive Evaluation Method is a comprehensive evaluation method based on fuzzy mathematics. It has the characteristics of clear results and strong systematization, and it can better solve fuzzy and difficult-to-quantify problems [38]. The technical indicator system constructed in this study is a qualitative indicator that have the problem of being fuzzy and difficult to quantify in the evaluation. Based on the comprehensive analysis of the characteristics of different comprehensive evaluation methods, the Fuzzy Comprehensive Evaluation Method was selected. The technical route of this study is shown in Figure 1. 


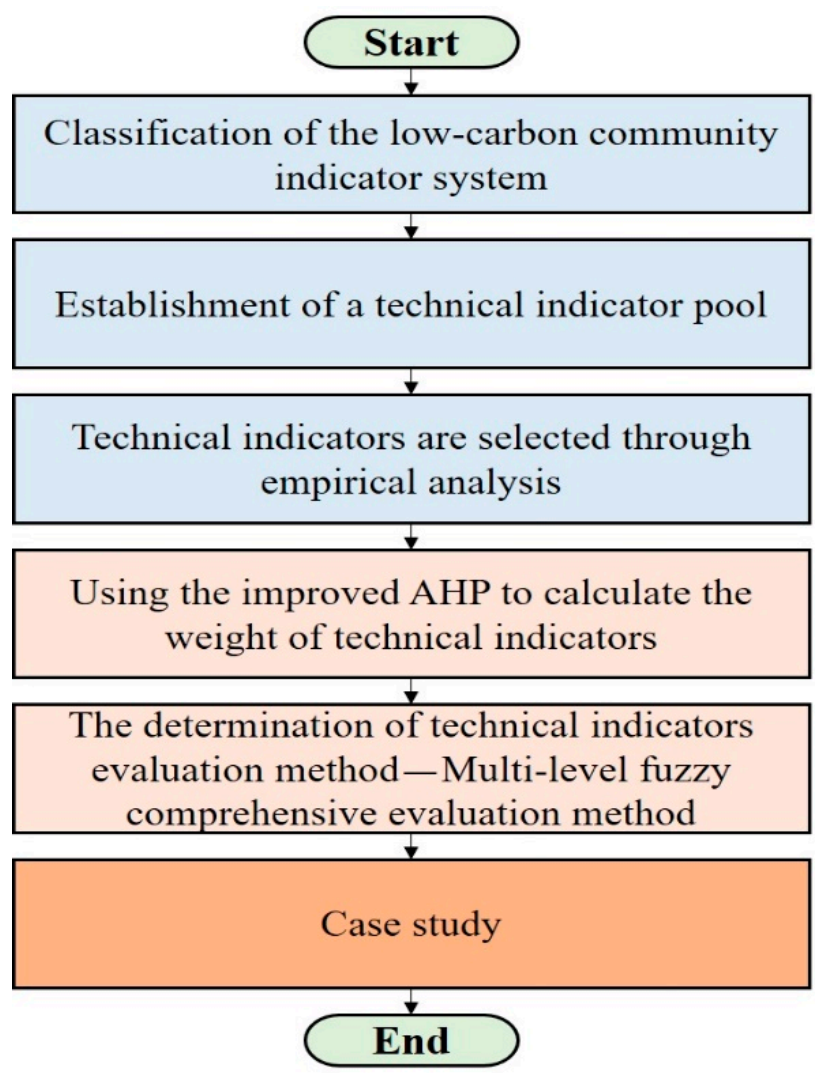

Figure 1. The technical route of the study.

\subsection{Classification of the Technical Indicator System}

Before constructing the evaluation technical indicator system for LCCs, it is necessary to clarify the classification of the indicator system for LCCs, which plays a very important role in the selection of the technical indicator and determines whether the technical indicator system is systematic $[39,40]$. At present, in China and the wider international context, there is the same definition of LCCs. It is generally believed that the construction of LCCs can reduce resource consumption and improve energy efficiency, thereby delaying global warming and ultimately achieving the development of a low-carbon economy [41,42]. Wang et al. [15] constructed an indicator system for LCCs based on six indicator categories: layout planning, transportation planning, architectural planning and design, environmental planning, municipal engineering planning, and construction management. Zhang et al. [43] analyzed the construction of indicators such as energy, transportation, waste management, and water management through cases in four communities. Jiang and Guo [18] summarized five aspects based on the successful experiences of two communities in terms of low-carbon planning including public participation, especially the important role of the government, making full use of energy, such as wind energy and solar energy, reasonable use of land, a reasonable layout of road traffic, and a convenient pedestrian transportation system.

To summarize, the indicator categories of LCCs mainly include building, transportation, land planning, and environmental life. In China, the construction of communities mainly involves three departments: building, transportation, and environment. In this study, the evaluation technical indicator system of LCCs was divided into three categories: low-carbon building, low-carbon transportation, and low-carbon environment. These three categories cover the main content of low-carbon community construction, and the indicators of each category can be managed by the corresponding departments. The following is an explanation of the three categories of indicators. 
1. Low-carbon building: Buildings are the main sources of carbon emissions in communities. At present, there is no construction standard for low-carbon building in China. In this study, the detailed technical indicators for the construction of lowcarbon building were established. The relevant evaluation technical indicators for the construction of LCCs that were established in this study were based on low-carbon buildings being used as a base point to radiate to low-carbon transportation and low-carbon environment.

2. Low-carbon transportation: Low-carbon transportation refers to optimizing a network structure, attaching importance to the construction of a slow-moving transportation system, and improving the convenience of a public transportation system. Every community needs to strengthen the management of motor vehicles and the application of advanced traffic management technology. At the same time, a community should pay attention to the promotion of low-carbon and environmentally friendly modes of transportation for residents.

3. Low-carbon environment: Low-carbon environment refers to scientific and reasonable community land layout planning, water environment planning, and household waste management. Low-carbon environment affects the choice of resident travel methods, which can create a good microclimate for a community and reduce environmental pollution.

\subsection{Screening Method for Technical Indicators}

\subsubsection{Establishment of Technical Indicator Pool}

In order to comprehensively construct the evaluation technical indicators of LCCs, in this research, a technical indicator pool was built by drawing on the concept of the topic pool in the "General Framework for Compiling Guidelines for Corporate Social Responsibility Reports in China". According to the research on the current development status of LCC assessments, all the main indicators related to LCCs, green ecological community, and sustainable community are defined in this framework.

China's indicator systems related to LCCs, which were mainly referred to in this study, include:

1. Technical announcement of the 11th Five Year Plan of the Ministry of Construction;

2. "Low carbon Housing Technology System Framework and Emission Reduction Indicators", issued by the China Real Estate Research Association and Housing Industry Development and Technology Committee;

3. "Key Points and Technical Guidelines for the Construction of Green Ecological Residential Areas", organized and compiled by the Housing Industrialization Promotion Center of the Ministry of Construction;

4. "Eco-residential Neighborhood Assessment Manual", published by the Industrialization Promotion Center Group, the Ministry of Construction; and

5. The Guide for Evaluation Technology for Low-Carbon Urban Areas and The Guide for Evaluation Technology for Low-Carbon Communities based on local Beijing standards.

The international common indicator system related to low-carbon communities that this study mainly referred to includes:

1. The LEED-ND formulated by the U.S. Green Building Council;

2. The BREEAM Communities formulated specifically for neighborhoods by the U.K.;

3. The CASBEE-UD created based on the CASBEE formulated by Japan, after taking into account urban areas and buildings.

\subsubsection{Empirical Analysis}

Empirical analysis is a method for comprehensively analyzing various factors based on researchers' professional knowledge and previous work experience. This method belongs to the category of qualitative analysis and has certain artificial subjectivity, but it is the most simple and feasible analysis method. In application, the method of increasing the number 
of researchers and synthesizing opinions can reduce subjectivity as much as possible and improve the accuracy of a conclusion [26]. As far as this study is concerned, there are many relevant evaluation technical indicators of LCCs, and there are overlapping concepts, inconsistent statistical calibers, and inconsistent data availability among some indicators. At the time of this study, the empirical analysis method could be used to compare and discriminate indicators to select the most appropriate evaluation technical indicators for LCCs. Experts judged each indicator according to the following standards: (1) each indicator is related to the community's carbon emissions; (2) each indicator should be logically related to each other; (3) the selected indicators should be typical and wraparound research field terms; (4) the indicators should be practical in a real situation and should be simple, accompanied by an explicit definition; (5) each indicator not only considers the present development condition of LCCs, but also includes the possibility of future development and changes. The results are denoted by "agreement, unsure, disagreement".

In the community, building carbon emissions, transportation carbon emissions, and living environment carbon emissions account for $54 \%, 40 \%$, and $6 \%$, respectively [44-46]. According to this feature, this study stipulated that the proportion of the number of experts in each field selected to the total number of experts should not be less than the proportion of carbon emissions in this field, so that more important indicators could be screened out. In addition, the experts selected by the research team have at least two professional backgrounds, which is to avoid the problem that experts with only one professional background often only choose indicators in their familiar field. A total of 24 experts were selected for this study. Experts in the field of building carbon emissions, transportation carbon emissions, and living environment carbon emissions accounted for $92 \%, 71 \%$, and $63 \%$, respectively, meeting the specified requirements. The results are shown in Table 1 . In each row, the number of filled circles represents the number of professions that the expert is familiar with. The three filled circles represent experts with professional backgrounds in the three fields. The two filled circles represent experts with professional backgrounds in the two fields. Experts were asked to select indicators by filling out questionnaires. When experts selected indicators, only the ones agreed by more than two-thirds of the experts were selected into the system, which ensures the scientificity of indicator selection. Experts screened the indicators in the technical indicator pool according to the above criteria, eliminated indicators not related to LCC construction, and developed specific descriptions for each removed indicator.

Table 1. Professional background information of 24 experts.

\begin{tabular}{|c|c|c|c|}
\hline Serial Numbers of the Experts & $\mathbf{A}$ & B & C \\
\hline 1 & $\bullet$ & • & • \\
\hline 2 & $\bullet$ & • & • \\
\hline 3 & $\bullet$ & & • \\
\hline 4 & $\bullet$ & & • \\
\hline 5 & $\bullet$ & $\bullet$ & \\
\hline 6 & $\bullet$ & & $\bullet$ \\
\hline 7 & $\bullet$ & $\bullet$ & \\
\hline 8 & $\bullet$ & $\bullet$ & \\
\hline 9 & $\bullet$ & & • \\
\hline 10 & $\bullet$ & & $\bullet$ \\
\hline 11 & $\bullet$ & $\bullet$ & \\
\hline 12 & $\bullet$ & & $\bullet$ \\
\hline 13 & • & & • \\
\hline 14 & & $\bullet$ & $\bullet$ \\
\hline 15 & $\bullet$ & $\bullet$ & • \\
\hline 16 & $\bullet$ & $\bullet$ & • \\
\hline 17 & $\bullet$ & $\bullet$ & • \\
\hline 18 & $\bullet$ & $\bullet$ & \\
\hline 19 & $\bullet$ & $\bullet$ & • \\
\hline 20 & $\bullet$ & $\bullet$ & \\
\hline
\end{tabular}


Table 1. Cont.

\begin{tabular}{cccc}
\hline Serial Numbers of the Experts & A & B & C \\
\hline 21 & $\bullet$ & $\bullet$ \\
22 & $\bullet$ & $\bullet$ \\
23 & $\bullet$ & $\bullet$ \\
24 & & $\bullet$
\end{tabular}

Note: "A" represents the field of building carbon emissions. "B" represents the field of transportation carbon emissions. "C" represents the field of living environment carbon emissions.

\subsection{Weight Calculation Method for the Technical Indicators}

\subsubsection{Improved AHP}

The technical evaluation indicators for low-carbon communities were characterized by strong systematization, wide coverage, and large quantities. The improved AHP was easy to operate, which overcame the difficulty of using fuzzy words such as "slightly" important, "relatively" important, and "extremely" important to express the relationship between the two elements accurately, and it did not require consistency tests to be conducted separately. The process was clear and simple.

1. After setting $\mathrm{n}$ indicators for a certain decision system A, i.e., $G_{1}, G_{2} \ldots G_{n}$, the corresponding weights were $W_{1}, W_{2} \ldots W_{n}$, and $W_{1}+W_{2}+\ldots+W_{n}=1$. In order to construct the judgment matrix, a comparison matrix was established using the three-scale method.

$$
C=\left(\begin{array}{cccc}
c_{11} & c_{12} & \ldots & c_{1 n} \\
c_{21} & c_{22} & \ldots & c_{2 n} \\
\vdots & \vdots & \vdots & \vdots \\
c_{n 1} & c_{n 2} & \ldots & c_{n n}
\end{array}\right)=\left(c_{i j}\right)_{n \times n}
$$

where, if $G i$ is more important than $G_{j}, c_{i j}$ is 1 ; if $G i$ is as important as $G_{j}, c_{i j}$ is 0 ; if $G i$ is less important than $G_{j}, c_{i j}$ is 1 .

2. The comparison matrix $C$ was used to calculate the optimal transfer matrix $O$ through mathematical conversion.

$$
\begin{gathered}
O_{i j}=\frac{1}{n} \sum_{t=1}^{n}\left(c_{i t}+c_{t j}\right) \\
O=\left(\begin{array}{cccc}
O_{11} & O_{12} & \ldots & O_{1 n} \\
O_{21} & O_{22} & \ldots & O_{2 n} \\
\vdots & \vdots & \vdots & \vdots \\
O_{n 1} & O_{n 2} & \ldots & O_{n n}
\end{array}\right)=\left(O_{i j}\right)_{n \times n}
\end{gathered}
$$

3. The optimal transfer matrix $O$ was transformed into the consistency matrix $D$, which was also called the judgment matrix of the indicator.

$$
\begin{aligned}
& D_{i j}=\exp \left(O_{i j}\right) \\
& D=\left(\begin{array}{cccc}
D_{11} & D_{12} & \ldots & D_{1 n} \\
D_{21} & D_{22} & \ldots & D_{2 n} \\
\vdots & \vdots & \vdots & \vdots \\
D_{n 1} & D_{n 2} & \ldots & D_{n n}
\end{array}\right)=\left(D_{i j}\right)_{n \times n}
\end{aligned}
$$

4. The solution for the eigenvector $W$ of $D$ was determined. 
The square root method was used to find $W=\left(W_{1}, W_{2}, \ldots, W_{n}\right)^{T}$, and the obtained eigenvector $W_{i}$ could be used as the weight of each indicator [31,32].

\subsubsection{Establishment of Tree Hierarchy Mode}

Before calculating the weight of technical indicators, the hierarchical structure of an indicator model is established first. The tree hierarchy model uses a "directed tree" data structure to represent various entities and the relationships between entities. Each node in the tree represents a record type, and there is a clear structure and simple relationship between nodes [47]. This model takes the research object as a system and makes decisions according to the thinking mode of decomposition, comparative judgment, and synthesis. It has become an important tool of system analysis developed after mechanism analysis and statistical analysis. The establishment of the index model with tree structure is of great significance to the research and calculation of index weight.

\subsection{Evaluation Method of Technical Indicators}

\subsubsection{Fuzzy Comprehensive Evaluation Method}

The fuzzy comprehensive evaluation method is a comprehensive evaluation method based on fuzzy mathematics, which is based on the fuzzy set theory [48,49]. The following is the basic principle of the fuzzy comprehensive evaluation method.

The evaluation target is regarded as a fuzzy set composed of many factors, which is called the factor set. Then, the evaluation level that these factors can select is set. The fuzzy set that makes up the evaluation is called the evaluation set. The membership grade of each single factor for each evaluation level is called the fuzzy matrix. Then, according to the weight distribution of various factors in the evaluation target, the quantitative solution of the evaluation is obtained through calculation (called fuzzy matrix synthesis). The specific steps are as follows.

1. Determination of the factor set of the evaluation object:

$$
U=\left\{u_{1}, u_{2}, \ldots, u_{m}\right\}
$$

where $U$ is the object of evaluation and $u_{m}$ is $m$ evaluation indices of the evaluation object.

2. Determination of the evaluation level set:

$$
V=\left\{v_{1}, v_{2}, \ldots, v_{n}\right\}
$$

For the evaluation target $U$, the evaluation results in $n$ may be made, $V$ represents the evaluation set of target $U$, and the specific level needs to be described in appropriate language according to the evaluation content. The ratings of the technical indicators screened out in this study were rated as "excellent", "good", "general", and "poor", as shown in Table 2.

Table 2. Ratings of the technical indicators.

\begin{tabular}{c} 
Specifications \\
\hline Ratings \\
$\begin{array}{c}\text { The application of the low-carbon technologies corresponding to the technical } \\
\text { indicator is in full compliance with the local climate, resources, and other } \\
\text { aspects. The specifications and installation position of the technical components } \\
\text { are reasonable, the construction meets the requirements, and the operation is in } \\
\text { good condition, which has a good effect on reducing carbon emissions. }\end{array}$ \\
The application of the low-carbon technologies corresponding to the technical \\
indicator is in line with the local climate, resources, and other aspects. The \\
specification and installation position of the technical components are relatively \\
reasonable, the construction essentially meets the requirements, and the \\
operation condition meets the relevant standards, which has a certain effect on \\
reducing carbon emissions.
\end{tabular}


Table 2. Cont.

\begin{tabular}{cc}
\hline Ratings & Specifications \\
General & $\begin{array}{c}\text { The application of low-carbon technologies corresponding to the technical } \\
\text { indicator did not fully meet the local conditions of climate and resources. The } \\
\text { specifications and installation position of the technical components are not } \\
\text { reasonable, the construction did not meet the corresponding requirements, and } \\
\text { the emission reduction effect achieved is limited. }\end{array}$ \\
Poor & $\begin{array}{c}\text { The application of low-carbon technologies corresponding to the technical } \\
\text { indicator did not conform to the local climate, resources, and other aspects, and } \\
\text { it had little effect on reducing carbon emissions, or there is no low-carbon } \\
\text { technology corresponding to this technical indicator. }\end{array}$ \\
\hline
\end{tabular}

By analyzing the detailed planning diagram, construction description diagram, actual operation report, and other relevant documents of a low-carbon community, relevant professionals can evaluate the technical indicators constructed in this study according to the evaluation criteria.

3. Single factor evaluation and establishment of the fuzzy relationship matrix $R$ :

$$
R=\left(\begin{array}{cccc}
R_{11} & R_{12} & \ldots & R_{1 n} \\
R_{21} & R_{22} & \ldots & R_{2 n} \\
\vdots & \vdots & \vdots & \vdots \\
R_{m 1} & R_{m 2} & \ldots & R_{m n}
\end{array}\right)
$$

where $R_{i j}(i=1,2, \ldots, m ; j=1,2, \ldots, n)$, indicating the membership degree of the evaluation target to the evaluation set $v_{j}$ from the perspective of the factor $u_{i}$. In this step, experts or relevant personnel usually evaluate each factor of the evaluation target. $R_{i j}$ refers to the ratio of the number of people whose evaluation result is $v_{j}$ to the total number of evaluators for factor $u_{i}$.

4. According to the factor weight $W=\left(W_{1}, W_{2}, \ldots, W_{n}\right)^{T}$ obtained by the improved $\mathrm{AHP}$, the evaluation result of $F$ is calculated.

$$
F=W \times R
$$

\subsubsection{Multi-Level Fuzzy Comprehensive Evaluation Method}

The evaluation technical indicator system of the LCCs is multi-level, so the multi-level fuzzy comprehensive evaluation method is needed. The principle is the same as that of the first level fuzzy comprehensive evaluation method, but the factor set $U$ is divided into $S$ subsets according to the type of attribute, and the subsets are recorded as $U 1, U 2, \ldots$, $U S$. For each subset $U i$, the fuzzy comprehensive evaluation is carried out according to the first-level model. After the evaluation results are obtained, each Ui is taken as an element to continue to build the evaluation matrix, and so on [50]. The comprehensive scoring system of the LCCs in this study was divided into four grades according to the comprehensive scoring results of the low-carbon level, namely, grade I, grade II, grade III, and grade IV. The details are shown in Table 3.

Table 3. Comprehensive rating of low-carbon communities.

\begin{tabular}{ccccc}
\hline Level & I & II & III & IV \\
\hline \multirow{3}{*}{ Total score } & Excellent & Good & Genera & Not low carbon \\
& $85-100$ & $70-85$ & $160-70$ & $0-60$ \\
& (including 85) & (including 70) & (including 60) & \\
\hline
\end{tabular}




\section{Results and Discussion}

\subsection{Technical Evaluation Indicators of LCC}

Through the establishment of the indicator pool and the empirical analysis of the indicator, the experts in the field of carbon emissions selected 34 indicators from the 73 indicators in the indicator pool. The selected indicators were highly systematic and scientific, and they fully represented the construction content of LCCs. The final determination results are shown in Table 4.

Table 4. Technical index and its specific explanation.

\begin{tabular}{|c|c|}
\hline Indicators & Specifications \\
\hline D1 Green planting system & $\begin{array}{l}\text { Tree transplantation technology, artificial greening cultivation technology, } \\
\text { and anti-seasonal planting technology }\end{array}$ \\
\hline D2 Roof greening system & $\begin{array}{l}\text { Light roof greening technology, thin substrate roof greening and vertical } \\
\text { cultivation technology, and planting concrete planting roof technology }\end{array}$ \\
\hline D3 Vertical greening system & Placement of suitable green plants on the exterior surface of a building \\
\hline D4 Solar energy utilization technology & $\begin{array}{l}\text { Passive solar energy utilization technology, solar power generation, solar } \\
\text { heating, solar light utilization, solar thermal utilization, solar air } \\
\text { conditioning, and refrigeration }\end{array}$ \\
\hline D5 Geo-energy utilization technology & $\begin{array}{l}\text { Geothermal power generation technology and geothermal heating } \\
\text { technology }\end{array}$ \\
\hline D6 Wind energy utilization technology & $\begin{array}{l}\text { Passive wind energy utilization technology and wind power generation } \\
\text { technology }\end{array}$ \\
\hline D7 Biomass energy utilization technology & Straw gasification technology, and biogas application technology \\
\hline D8 Wall & $\begin{array}{l}\text { Wall insulation technology, coating insulation technology, and phase change } \\
\text { wall materials }\end{array}$ \\
\hline D9 Roof & $\begin{array}{c}\text { Ventilation roofing, thermal insulation roofing, cold roof systems, and water } \\
\text { storage roofing }\end{array}$ \\
\hline D10 Door and window & $\begin{array}{c}\text { Broken bridge energy-saving windows, composite energy-saving windows, } \\
\text { and insulating glass doors and windows (inert gas insulating glass, low-E } \\
\text { insulating glass) }\end{array}$ \\
\hline D11 Shading technology & $\begin{array}{l}\text { External shading systems, internal shading systems, body shading systems } \\
\text { (hollow glass louver shading technology), and light-guided shading systems }\end{array}$ \\
\hline D12 Building ground system & Floating floors, overhead floors, and phase change heat storage floors \\
\hline D13 Water supply and drainage system & $\begin{array}{l}\text { Water supply and drainage system optimization technology and } \\
\text { water-saving appliances }\end{array}$ \\
\hline D14 Heating system & $\begin{array}{l}\text { Pipe insulation technology, central heating technology, decentralized heating } \\
\text { technology, and heating supply end systems }\end{array}$ \\
\hline D15 Ventilation system & $\begin{array}{l}\text { Passive ventilation systems and high efficiency and energy-saving } \\
\text { ventilation systems }\end{array}$ \\
\hline D16 Lighting system & $\begin{array}{l}\text { High efficiency and energy-saving lamp systems, light guide lighting } \\
\text { systems, and light collection lighting systems }\end{array}$ \\
\hline D17 Air conditioning system & $\begin{array}{l}\text { Ice water storage air conditioning systems, air conditioning systems, variable } \\
\text { air volume air conditioning systems, and air conditioning water systems }\end{array}$ \\
\hline D18 Intelligent monitoring system & $\begin{array}{c}\text { Intelligent lighting control systems, air conditioning, heating and ventilation } \\
\text { equipment intelligent control systems, electrical equipment remote } \\
\text { intelligent control systems }\end{array}$ \\
\hline D19 Property management system & $\begin{array}{l}\text { Waste disposal systems, building property intelligent management centers, } \\
\text { and building property digital management control platforms }\end{array}$ \\
\hline
\end{tabular}

D20 Design technology for building outdoor environment

Reasonable building spacing, building plot ratios, and building densities 
Table 4. Cont.

\section{Indicators}

D21 Building design technology

22 High-quality public transportation system

\section{Specifications}

Building shape coefficient controls, window wall ratio controls, and building orientation design

The establishment of intelligent public transportation microcirculation networks, the establishment of one-stop transportation platforms, and the distance from the entrance and exit to the public transport station conforming to the national high quality public transport requirements

The establishment of a people-oriented slow traffic system (high-quality bicycle and pedestrian transportation network suitable for residents)

The implementation of the strict management of motor vehicle demand policies and encouraging the use of new energy vehicles

D24 Motor vehicle demand management

Encouraging the use of clean energy vehicles and implementing strict energy consumption and emission management standards

D25 Strict management standard for energy consumption and emission

D26 Advanced traffic management technology

Road traffic data collection, scientific transmission and processing information, and real-time release of traffic operation information

With comprehensive diversified functional space, the intensive use of land can be achieved, and a community functional network can be formed to meet the needs of diversified and multi-level activities

Advocating for rational population size and diversified land use, shortening the distance between activity spaces and families, reducing pollution and energy consumption

The establishment of balanced public service facilities to facilitate the life and travel of residents

D29 Balanced layout of public service facilities

The roof use of rainwater and ground infiltration use of rainwater

D30 Rainwater collection technology

After the centralized treatment of domestic wastewater (bathing, washing,

D31Recycled water reuse technology

kitchen, and toilet), the wastewater can be reused for greening irrigation, vehicle washing, road washing, and household toilet flushing

D32 Permeable ground and constructed wetland Increasing the proportion of permeable surfaces to rechargeable groundwater technology sources and establishing artificial wetlands

The waste disposal and recycling in the community to achieve the goal of the sustainable development of the community and to reduce the pollution to the environment

The establishment of waste sorting collection devices and treatment and transportation systems

\subsection{Weight Calculation for Technical Indicators}

\subsubsection{Tree Hierarchy Model of Technical Indicators}

In this study, the hierarchical structure of the indicator model was divided into the target layer, primary indicator, secondary indicator, and tertiary indicator. First, the target layer was composed of LCCs. The division of the primary indicator was determined according to the three categories of the technical indicator system. The primary indicator could be divided into low-carbon building, low-carbon transportation, and low-carbon environment. The secondary indicator was determined according to the category of the screened indicator, and the tertiary indicator was the specific screened technical indicator. Indicators at all levels are shown in Table 5, and the hierarchy structure of the index model is shown in Figure 2.

\subsubsection{Calculating the Weights of the Technical Indicators}

In the process of calculating the index weight, 24 experts with two or more professional backgrounds in low-carbon fields were selected in this study. These experts comprehensively considered when comparing the weights of indicators, which avoided 
the problem that they tended to score a certain indicator higher due to cognitive limitations. The departments to which these experts belonged included universities, urban planning and design institutes, and government management departments. Experts in universities mainly considered problems from the level of basic theoretical knowledge, experts in urban planning and design institutes mainly considered problems from the aspect of practicability, and experts in government management departments mainly considered problems from the aspects of economic benefits and community management. Therefore, the calculated index weight was considered in different aspects, which increased the scientificity of index weight. In order to further eliminate the imbalance of index weight, the index weight given by all experts was arithmetically averaged. In this study, the Delphi method was used to issue the questionnaire, which made experts make a more objective and reasonable evaluation of the index weight. By programming the improved AHP with MATLAB and computing the collected questionnaire data, the weights of the indicators at all levels relative to the target layer were obtained, as shown in Figures 3-5.

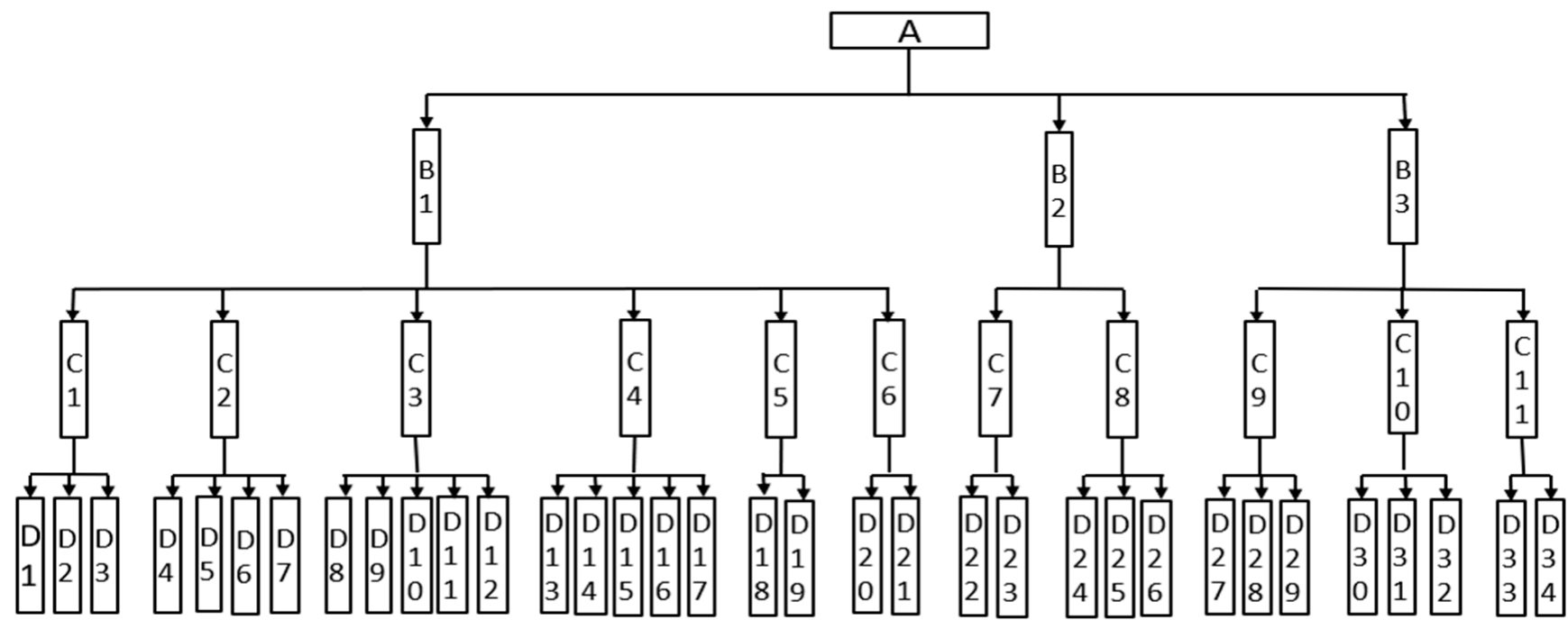

Figure 2. Hierarchical diagram of technical evaluation indicators for LCCs.

B1

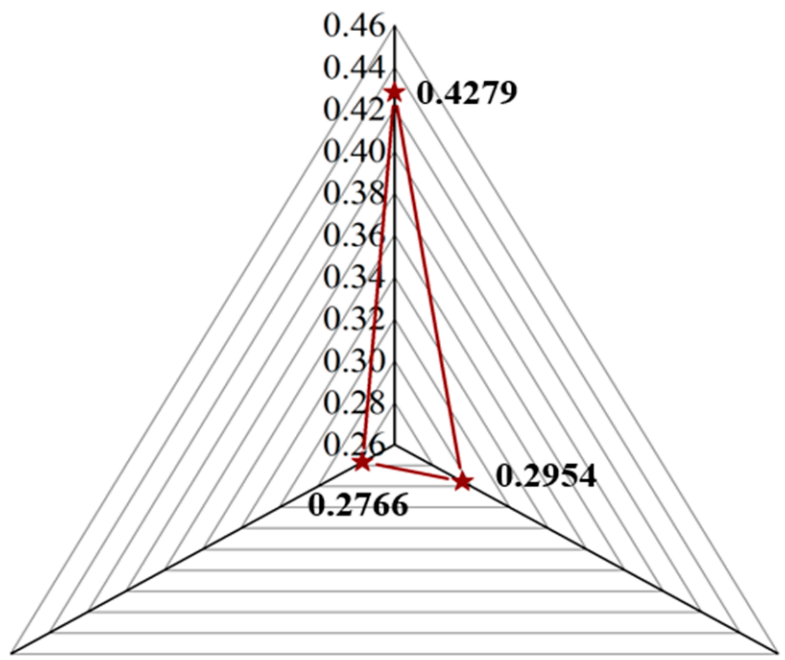

B3

Figure 3. Radar for primary indicator weights. 
Table 5. Indicators for all levels of low-carbon communities.

\begin{tabular}{|c|c|c|c|}
\hline $\begin{array}{l}\text { Target } \\
\text { Layer }\end{array}$ & Primary Indicator & $\begin{array}{l}\text { Secondary } \\
\text { Indicator }\end{array}$ & $\begin{array}{l}\text { Tertiary } \\
\text { Indicator }\end{array}$ \\
\hline \multirow{11}{*}{ A LCC } & \multirow{6}{*}{ B1 Low-carbon building } & $\begin{array}{l}\text { C1 Low-carbon technology of } \\
\text { greening system }\end{array}$ & $\begin{array}{l}\text { D1 Green planting system, D2 Roof greening } \\
\text { system, D3 Vertical greening system }\end{array}$ \\
\hline & & $\begin{array}{l}\text { C2 Low-carbon technology for } \\
\text { building energy supply }\end{array}$ & $\begin{array}{l}\text { D4 Solar energy utilization technology, D5 } \\
\text { Geo-energy utilization technology, D6 Wind } \\
\text { energy utilization technology, D7 Biomass } \\
\text { energy utilization technology }\end{array}$ \\
\hline & & $\begin{array}{l}\text { C3 Low-carbon technology for } \\
\text { building envelope }\end{array}$ & $\begin{array}{l}\text { D8 Wall, D9 Roof, D10 Door and window, } \\
\text { D11 Shading technology, D12 Building } \\
\text { ground system }\end{array}$ \\
\hline & & $\begin{array}{l}\text { C4 Low-carbon technology for } \\
\text { building equipment }\end{array}$ & $\begin{array}{c}\text { D13 Water supply and drainage system, D14 } \\
\text { Heating system, D15 Ventilation system, D16 } \\
\text { Lighting system, D17 Air conditioning } \\
\text { system }\end{array}$ \\
\hline & & $\begin{array}{l}\text { C5 Low-carbon technology for } \\
\text { building operation } \\
\text { management }\end{array}$ & $\begin{array}{l}\text { D18 Intelligent monitoring system, D19 } \\
\text { Property management system }\end{array}$ \\
\hline & & $\begin{array}{l}\text { C6 Low-carbon technology of } \\
\text { building design }\end{array}$ & $\begin{array}{c}\text { D20 Design technology for building outdoor } \\
\text { environment, D21 Building design } \\
\text { technology }\end{array}$ \\
\hline & \multirow[b]{2}{*}{ B2 Low-carbon transportation } & C7 Road planning & $\begin{array}{l}\text { D22 High-quality public transportation } \\
\text { system, D23 Slow traffic network }\end{array}$ \\
\hline & & C8 Traffic management & $\begin{array}{l}\text { D24 Motor vehicle demand management, } \\
\text { D25 Strict management standard for energy } \\
\text { consumption and emission, D26 Advanced } \\
\text { traffic management technology }\end{array}$ \\
\hline & \multirow{3}{*}{ B3 Low-carbon environment } & C9 Land layout planning & $\begin{array}{l}\text { D27 Land utilization pattern of } \\
\text { multi-functional mix, D28 Compact space } \\
\text { pattern for low-carbon community, D29 } \\
\text { Balanced layout of public service facilities }\end{array}$ \\
\hline & & $\begin{array}{l}\text { C10 Water environment } \\
\text { planning }\end{array}$ & $\begin{array}{c}\text { D30 Rainwater collection technology, D31 } \\
\text { Recycled water reuse technology, D32 } \\
\text { Permeable ground and constructed wetland } \\
\text { technology }\end{array}$ \\
\hline & & $\begin{array}{l}\text { C11 Domestic waste } \\
\text { management }\end{array}$ & $\begin{array}{c}\text { D33 Solid waste disposal and recycling } \\
\text { technology, D34 Garbage classification and } \\
\text { collection }\end{array}$ \\
\hline
\end{tabular}

Among the primary indicators, B1 had the largest weight ratio, which was about 0.4279. Buildings are the largest carbon emission source in a community. Therefore, it is necessary to strengthen the construction of low-carbon building in the construction of low-carbon communities and make good use of various energy-saving and emission reduction measures. The weight of B2 and B3 accounted for about 0.28 , and these two indicators had similar effects on low-carbon communities.

Among the secondary indicators, the top four were $\mathrm{C} 7, \mathrm{C} 9, \mathrm{C} 8$, and $\mathrm{C} 2$, accounting for $0.1733,0.1271,0.1221$, and 0.0888 , respectively. The construction of C7, C9, and C8 was mainly to reduce the travel by private cars, use public transportation as far as possible, and travel by walking in order to reduce the traffic carbon emissions. C2 low-carbon technology for building energy supply is a very important link in the construction of low-carbon buildings. Choosing appropriate renewable energy technology according to local natural resources is a very important way to reduce the carbon emissions of buildings. Among 
all the secondary indicators, the proportion of $\mathrm{C} 1$ was the lowest, which showed that compared with other indicators, the impact on the construction of LCCs was small.

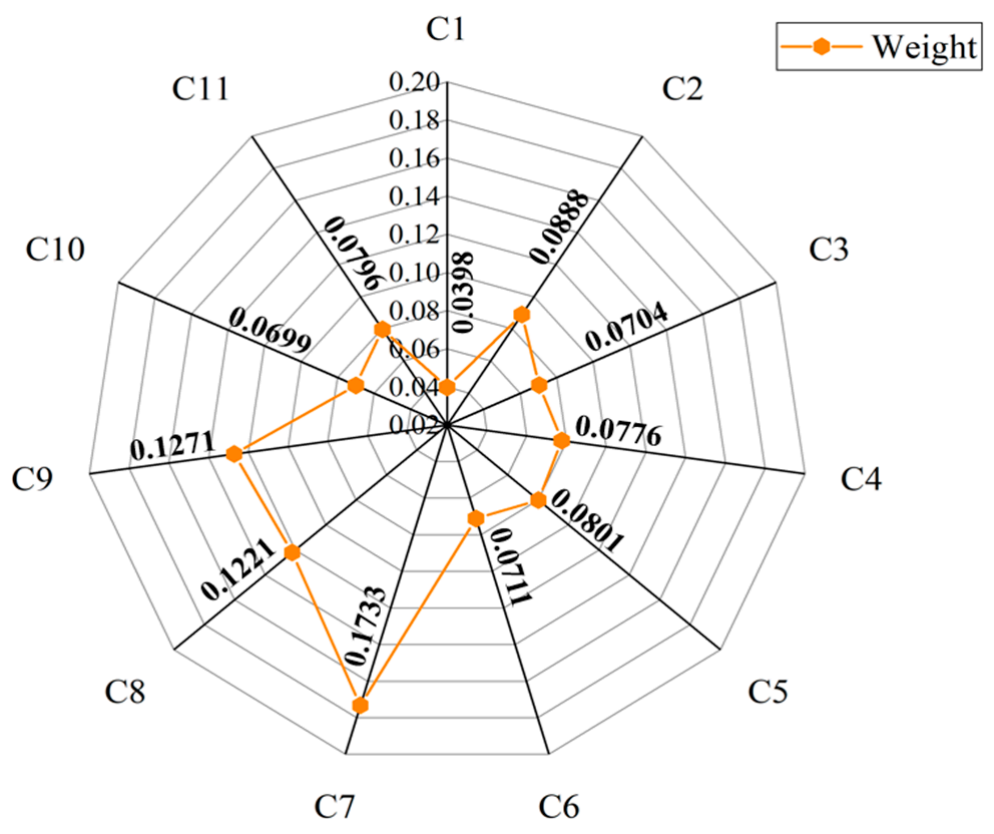

Figure 4. Radar for secondary indicator weights.

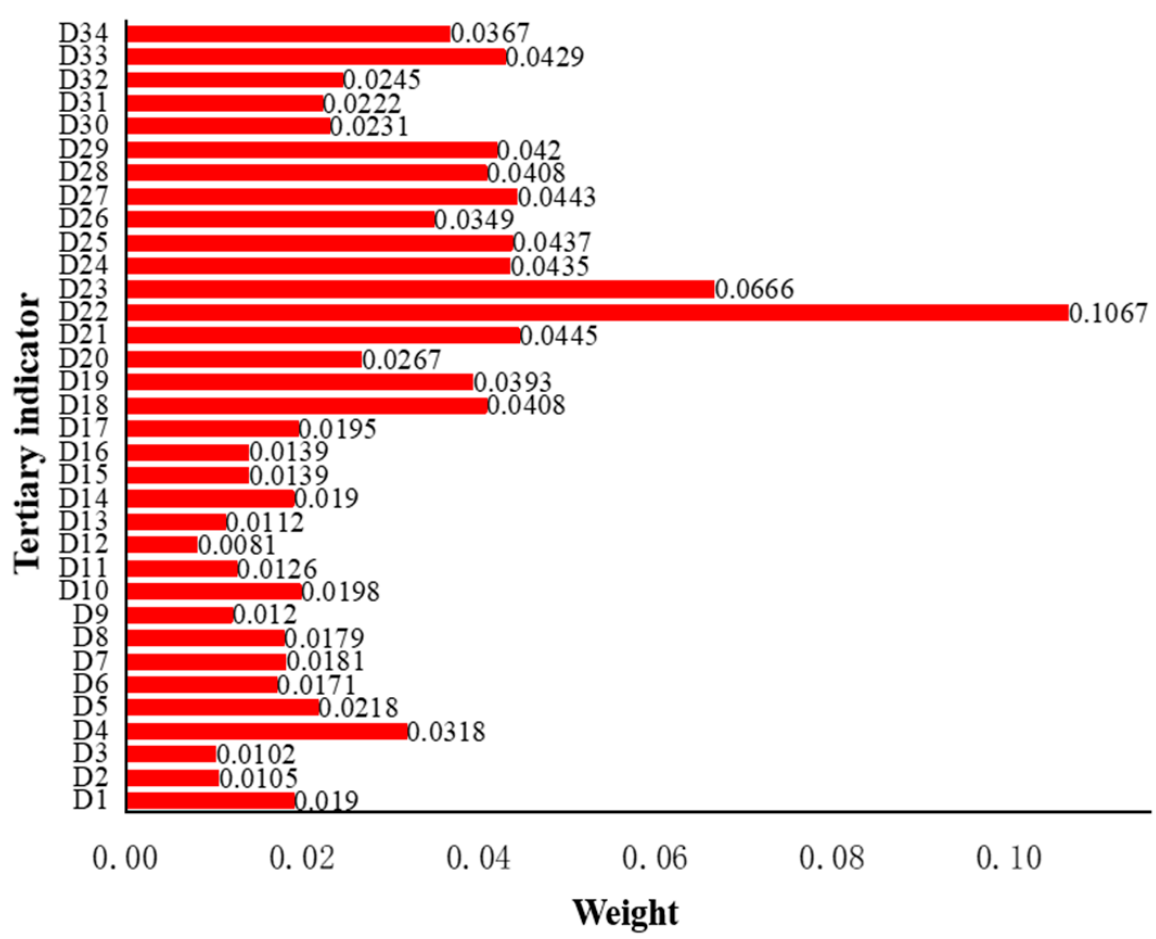

Figure 5. A bar chart for the tertiary indicator weights.

Among the tertiary indicators, according to the categories of B1, B2, and B3, the indicators at their respective levels were analyzed and discussed in order to be more meaningful for the construction of low-carbon communities. Within the scope of B1, the top-ranking indicators were D21, D18, D19, and D4. The scientific and reasonable building design is the premise of building utilization of natural resources. D18 and D19 
play an important role in the operation of buildings and determine whether buildings can save energy efficiently. D4 is the most widely used and most mature technology in buildings [51,52]. The electricity and heat generated by solar energy reduce the dependence on traditional energy and play an important role in energy conservation and emission reduction. Within the scope of B2, the top-ranking indicators were D22, D23, D25, and D24. D22 and D23 are the most important indicators of low-carbon transportation planning, and they play an important role in reducing or even replacing private car travel. High-quality road planning can form a convenient system for public travel and pedestrian travel, and it can reduce a large number of traffic carbon emissions. In the B3 scope, the top-ranking indicators were D33, D29, and D28. The construction of D33 strengthens the utilization of resource cycle, and it is a landmark indicator for low-carbon communities to save resources and reduce energy consumption. D29 can facilitate the clothing, food, housing, and transportation of residents, reduce travel time, and promote the use of non-motor vehicles to travel for residents. D28 is conducive to the saving of land. The moderate increase in floor area ratios and building densities can effectively reduce road paving areas and the length of facilities and pipelines, and reduce the impact on ecological factors.

\section{Case Study}

In order to verify the practicality of the evaluation index system and the availability of index data, it was necessary to test the index system and apply it to the evaluation of actual communities. The study selected two communities as the application objects of the index system. The first community is the Tianjin Eco-city "Shimao New Town" community. The community is located on the north side of the Yongdingzhou Wetland Ecological Park and on the south side of the National Animation Industry Park, with a total area of 1.46 square kilometers. The "Shimao New Town" community was established in 2014. The community adopted a variety of energy-saving technologies. It is a typical green energy-saving community and has achieved suitable evaluation. The second community is the "Dongming" community under the jurisdiction of Shanghai's Pudong New Area, covering an area of 5.95 square kilometers. The community was established in 1999 and is an older community with relatively few applications of green energy-saving technologies.

By consulting the detailed planning documents and construction documents of the two communities, the low-carbon technologies used in community construction were sorted out. Ten experts from Beijing urban community planning and design institutes were invited. They have been engaged in low-carbon planning and design and actual construction of communities for a long time, and they are all professionals with senior professional titles. These experts have rich experience in the application of the index system. Each expert evaluated the low-carbon technologies adopted by the two communities and determined the rating of the tertiary indicators. Through the transformation of the multi-level fuzzy comprehensive evaluation method, the comprehensive scores of the two communities and the scores of primary and secondary indicators are shown in Tables 6 and 7. The score of the "Shimao New Town" community was 78, and it belonged to the II level. According to the comprehensive score of the LCCs, it could be concluded that the community was a better LCC, and some suggestions could be summarized from the scores of the indicators at all levels to guide the future construction of the community. It could be seen from the scores of the primary indicators that the low-carbon construction of B1 and B2 was better, and the low-carbon construction of B3 was poor. In terms of the construction of B1, the buildings in the "Shimao New Town" community adopted many green energy-saving technologies and had a good score. However, as can be seen from the scores of the secondary indicators, the construction of low-carbon technologies for a green system and building energy supply needed to be strengthened in the B1 field. The low-carbon construction of the community should adopt a variety of greening methods, such as the vertical greening of the building facade, the greening of the roof, and the greening of the area around the building. Buildings should make use of various forms of renewable energy technologies according to local conditions to reduce the use of traditional energy. The score of B2 was relatively high, and 
the low-carbon construction of road planning and traffic management was better. The "Shimao New Town" community focused on the construction of a slow traffic network and established a public transportation-oriented transportation system. Within the scope of B3, the scores of all indicators were relatively low, and the community needed to be further improved in terms of community compactness, rainwater collection and utilization, and waste recycling. The score of the "Dongming" community was 66, belonging to the III level. The community was a general low-carbon community. It could be seen from the scores of the primary indicators that the scores of B1 and B2 were relatively low, and the score of B3 was relatively high. The score of B1 was relatively low because the "Dongming" community was established earlier, and most buildings did not adopt suitable low-carbon and energy-saving technologies. The technical indicators contained in B1 needed to be further improved. The "Dongming" community did not pay attention to the planning and construction of low-carbon transportation in the construction stage, which led to the low score of B2. In the later period, the community implemented stricter traffic management policies to reduce traffic carbon emissions. Therefore, the secondary indicator $\mathrm{C} 8$ contained in B2 had a high score. The "Dongming" community had a better low-carbon construction in B3, because the community implemented energy-saving and emission-reduction policies in terms of low-carbon environment, including garbage classification, waste recycling, and rainwater recycling. It could be seen from the secondary indicators included in B3 that the community achieved relatively excellent scores in the construction of C10 and C11.

Table 6. Scores of the target layer and the indicator layers at all levels.

\begin{tabular}{|c|c|c|c|c|c|}
\hline Target Layer A & $\begin{array}{l}\text { Total Score of } \\
\text { Target Layer }\end{array}$ & Primary Indicator B & $\begin{array}{c}\text { Score of Each } \\
\text { Primary Indicator }\end{array}$ & Secondary Indicator C & $\begin{array}{l}\text { Score of Each } \\
\text { Secondary } \\
\text { Indicator }\end{array}$ \\
\hline \multirow{11}{*}{ LCC } & \multirow{11}{*}{78} & \multirow{6}{*}{$\begin{array}{l}\text { B1 Low-carbon } \\
\text { building }\end{array}$} & \multirow{6}{*}{78} & $\begin{array}{l}\text { C1 Low-carbon } \\
\text { technology of greening } \\
\text { system }\end{array}$ & 68 \\
\hline & & & & $\begin{array}{l}\text { C2 Low-carbon } \\
\text { technology for building } \\
\text { energy supply }\end{array}$ & 52 \\
\hline & & & & $\begin{array}{l}\text { C3 Low-carbon } \\
\text { technology for building } \\
\text { envelope }\end{array}$ & 82 \\
\hline & & & & $\begin{array}{c}\text { C4 Low-carbon } \\
\text { technology for building } \\
\text { equipment }\end{array}$ & 73 \\
\hline & & & & $\begin{array}{l}\text { C5 Low-carbon } \\
\text { technology for building } \\
\text { operation management }\end{array}$ & 98 \\
\hline & & & & $\begin{array}{c}\text { C6 Low-carbon } \\
\text { technology of building } \\
\text { design }\end{array}$ & 96 \\
\hline & & \multirow{2}{*}{$\begin{array}{l}\text { B2 Low-carbon } \\
\text { transportation }\end{array}$} & \multirow[b]{2}{*}{97} & C7 Road planning & 98 \\
\hline & & & & C8 Traffic management & 95 \\
\hline & & \multirow{3}{*}{$\begin{array}{l}\text { B3 Low-carbon } \\
\text { environment }\end{array}$} & \multirow{3}{*}{58} & C9 Land layout planning & 64 \\
\hline & & & & $\begin{array}{l}\text { C10 Water environment } \\
\text { planning }\end{array}$ & 64 \\
\hline & & & & $\begin{array}{l}\mathrm{C} 11 \text { Domestic waste } \\
\text { management }\end{array}$ & 45 \\
\hline
\end{tabular}


Table 7. Scores of the target layer and the indicator layers at all levels.

\begin{tabular}{|c|c|c|c|c|c|}
\hline Target Layer A & $\begin{array}{c}\text { Total Score of Target } \\
\text { Layer }\end{array}$ & Primary Indicator B & $\begin{array}{c}\text { Score of Each } \\
\text { Primary Indicator } \\
\end{array}$ & $\begin{array}{c}\text { Secondary Indicator } \\
\text { C }\end{array}$ & $\begin{array}{c}\text { Score of Each } \\
\text { Secondary Indicator }\end{array}$ \\
\hline \multirow{11}{*}{ LCC } & \multirow{11}{*}{66} & \multirow{6}{*}{$\begin{array}{l}\text { B1 Low-carbon } \\
\text { building }\end{array}$} & \multirow{6}{*}{58} & $\begin{array}{l}\text { C1 Low-carbon } \\
\text { technology of } \\
\text { greening system }\end{array}$ & 69 \\
\hline & & & & $\begin{array}{l}\text { C2 Low-carbon } \\
\text { technology for } \\
\text { building energy } \\
\text { supply }\end{array}$ & 44 \\
\hline & & & & $\begin{array}{l}\text { C3 Low-carbon } \\
\text { technology for } \\
\text { building envelope }\end{array}$ & 70 \\
\hline & & & & $\begin{array}{l}\text { C4 Low-carbon } \\
\text { technology for } \\
\text { building equipment }\end{array}$ & 60 \\
\hline & & & & $\begin{array}{l}\text { C5 Low-carbon } \\
\text { technology for } \\
\text { building operation } \\
\text { management }\end{array}$ & 49 \\
\hline & & & & $\begin{array}{l}\text { C6 Low-carbon } \\
\text { technology of } \\
\text { building design }\end{array}$ & 66 \\
\hline & & \multirow{2}{*}{$\begin{array}{l}\text { B2 Low-carbon } \\
\text { transportation }\end{array}$} & \multirow[b]{2}{*}{59} & C7 Road planning & 44 \\
\hline & & & & $\begin{array}{c}\text { C8 Traffic } \\
\text { management }\end{array}$ & 81 \\
\hline & & \multirow{3}{*}{$\begin{array}{l}\text { B3 Low-carbon } \\
\text { environment }\end{array}$} & \multirow{3}{*}{84} & $\begin{array}{l}\text { C9 Land layout } \\
\text { planning }\end{array}$ & 80 \\
\hline & & & & $\begin{array}{l}\text { C10 Water } \\
\text { environment } \\
\text { planning }\end{array}$ & 85 \\
\hline & & & & $\begin{array}{l}\text { C11 Domestic waste } \\
\text { management }\end{array}$ & 90 \\
\hline
\end{tabular}

Figure 6 compared the scores of target layers and indicators at all levels of the two communities. As can be seen from Figure 6, the target layer score of the "Shimao New Town" community was higher than that of the "Dongming" community. The "Shimao New Town" community was well built in terms of low-carbon building and low-carbon transportation. In the field of low-carbon building, almost all technical indicators of the "Shimao New Town" community were better than those of the "Dongming" community, especially the construction of C5 and C6. In the field of low-carbon transportation, the "Shimao New Town" community was ahead of the "Dongming" community in the construction of $\mathrm{C} 7$ and $\mathrm{C} 8$. In terms of $\mathrm{C} 7$ construction, there was an obvious gap between the "Dongming" community and the "Shimao New Town" community. In the field of low-carbon environment, the "Dongming" community was better than the "Shimao New Town" community in various indicators. The two communities could learn from each other and further strengthen the application of low-carbon technologies for indicators with low scores. 


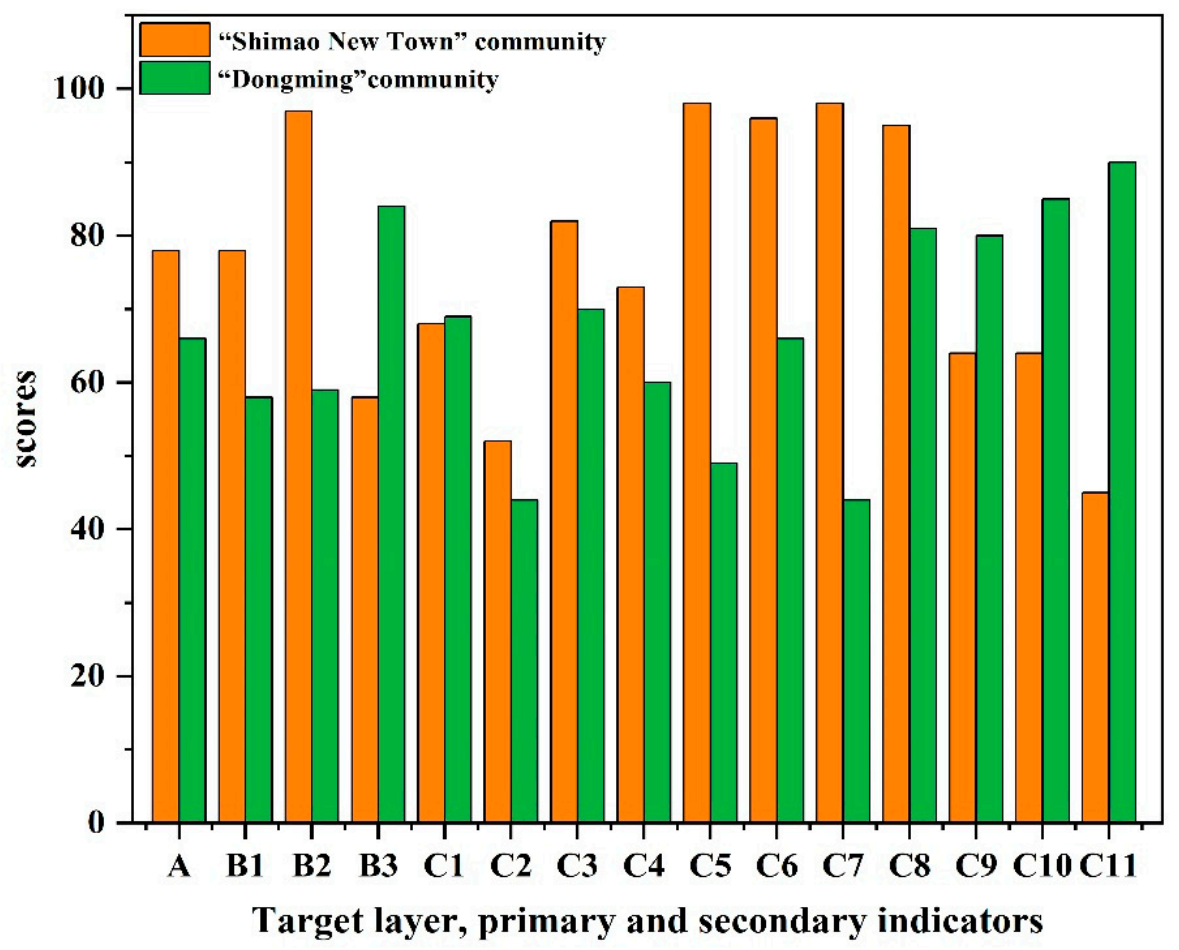

Figure 6. Scores of target levels and indicators at all levels of the two communities.

\section{Conclusions}

The study established a technical evaluation index system for low-carbon communities. According to the existing indicator for LCC construction, an indicator pool was established, and the relevant technical indicators of LCC construction were selected through empirical analysis. The improved AHP was selected to calculate the weight of the index, and the multi-level fuzzy comprehensive evaluation method was determined to be the evaluation method of the technical indicator.

On the above basis, the two typical communities in Tianjin and Shanghai were selected to verify the operability of the index system. The indicator system constructed in this study gave a reasonable low-carbon level for the two communities, which was in line with the actual low-carbon construction status of each community. In addition, for the lowcarbon community in Tianjin with high scores, the evaluation results pointed out that the community had better construction in low-carbon building and low-carbon transportation indicators, and further pointed out that the community needed to strengthen the application of low-carbon technology of the greening system and building energy supply in the field of low-carbon building. In terms of the relatively poor low-carbon environmental indicators of the community, the evaluation results pointed out that the community needed to be further improved in terms of community compactness, rainwater collection and utilization, and waste recycling. For the low-carbon community in Shanghai with low scores, the evaluation results showed the advantages and disadvantages of the community in the construction of low-carbon building, low-carbon transportation, and low-carbon environment indicators. The community applied few low-carbon technologies in low-carbon building and needed to promote the application of various low-carbon technologies. Regarding the construction of low-carbon transportation, the evaluation results pointed out that the community needed to further strengthen the construction of road planning. The low-carbon environment construction of the community was relatively suitable, which could provide experience for the low-carbon construction of other communities. The indicator system can not only evaluate the degree of low carbon in a community, but also indicate the aspects in which a community needs to strengthen the use of low carbon technology, which can be used as a tool for community planning and construction personnel to evaluate the construction progress and degree of low carbon in LCCs. Furthermore, the method of constructing 
the technical index system in this study can provide a reference for future qualitative research. In the low-carbon construction of communities, planners should pay attention to the construction of low-carbon buildings, which is of great significance to the construction of low-carbon communities.

However, the study does have limitations. The empirical analysis method and improved AHP method used in this study are subjective methods, and the application scope of these methods needs to be further explored. In terms of the selection of the number of experts and the selection of indicators, more scientific methods need to be studied. The weight of indicators needs further analysis and discussion. Furthermore, in addition to establishing a qualitative evaluation index system for low-carbon communities, carbon measurement and quantitative evaluation of communities should also be considered. It is necessary to determine how to combine a qualitative technical indicator system with carbon dioxide emissions.

Author Contributions: Conceptualization, Y.B. and W.Z.; methodology, Y.B. and W.Z.; software, Y.B.; validation, Y.B. and W.Z.; formal analysis, Y.B. and W.Z.; investigation, W.Z. and X.Y.; resources, W.Z. and Y.Y.; data curation, Y.B., W.Z. and Y.Y.; writing—original draft preparation, Y.B. and W.Z.; writing-review and editing, W.Z., X.Y. and S.W.; visualization, Y.B., W.Z. and S.W.; supervision, W.Z., X.Y. and S.W.; project administration, W.Z. and Y.Y. All authors have read and agreed to the published version of the manuscript.

Funding: The research described in this paper was supported by the National Key R\&D Program of China "Optimization Technology for Urban New District Planning and Design" (2018YFC0704600).

Institutional Review Board Statement: Not applicable.

Informed Consent Statement: Not applicable.

Data Availability Statement: The data presented in this study are available on request from the corresponding author.

Acknowledgments: The author would like to thank the experts in the field of carbon emission in the Institute for Sustainable Development Goals, Tsinghua University, and the technicians of Tianjin Eco-city.

Conflicts of Interest: We declare that we have no financial and personal relationships with other people or organizations that can inappropriately influence our work, there is no professional or other personal interest of any nature or kind in any product, service and/or company that could be construed as influencing the position presented in, or the review of, the manuscript entitled "The framework of technical evaluation indicators for constructing low-carbon communities in China".

\section{References}

1. Ssaa, B.; Aaac, D.; Ow, E.; Muee, F. The role of electricity consumption, globalization and economic growth in carbon dioxide emissions and its implications for environmental sustainability targets. Sci. Total Environ. 2020, 708, 134653.

2. Gu, G.; Wang, Z.; Wu, L. Carbon emission reductions under global low-carbon technology transfer and its policy mix with $\mathrm{r} \& \mathrm{~d}$ improvement. Energy 2021, 216, 119300.

3. Cuffey, K.M.; Vimeux, F. Covariation of carbon dioxide and temperature from theVostok ice core after deuterium-excess correction. Nature 2001, 412, 523-527. [CrossRef]

4. Seto, K.C.; Satterthwaite, D. Interactions between urbanization and global environmental change. Curr. Opin. Environ. Sustain. 2010, 2, 127-128. [CrossRef]

5. Yang, J.; Zhan, Y.; Xiao, X.; Xia, J.C.; Sun, W.; Li, X. Investigating the diversityof land surface temperature characteristics in different scale cities based on local climate zones. Urban Clim. 2020, 34, 100700. [CrossRef]

6. Zhang, Y.; Liu, Y.; Wang, Y.; Liu, D.; Xia, C.; Wang, Z. Urban expansion simulation towards low-carbon development: A case study of Wuhan, China. Sustain. Cities Soc. 2020, 63, 102455. [CrossRef]

7. Lee, W.L.; Burnett, J. Benchmarking energy use assessment of hk-beam, breeam and leed. Build. Environ. 2008, 43, 1882-1891. [CrossRef]

8. Perez, M.; Rey, E. A multi-criteria approach to compare urban renewal scenarios for an existing neighborhood. case study in lausanne (switzerland). Build. Environ. 2013, 65, 58-70. [CrossRef]

9. Duo, C.; Deng, Z.; Liu, Z. China's non-fossil fuel CO2 emissions from industrial processes. Appl. Energy 2019, 254, 113537.

10. Song, D.; Su, M.; Yang, J.; Chen, B. Greenhouse gas emission accounting and management of low-carbon community. Sci. World J. 2012, 2012. [CrossRef] 
11. Yildırım, M.; Topkaya, B. Assessing environmental impacts of wastewater treatment alternatives for small-scale communities. CLEAN-Soil Air Water 2012, 40, 171-178. [CrossRef]

12. Lin, X.; Ren, J.; Xu, J.; Zheng, T.; Cheng, W.; Qiao, J.; Huang, J.; Li, G. Prediction of Life Cycle Carbon Emissions of Sponge City Projects: A Case Study in Shanghai, China. Sustainability 2018, 10, 3978. [CrossRef]

13. Sharifi, A.; Murayama, A. Neighborhood sustainability assessment in action: Cross-evaluation of three assessment systems and their cases from the US, the UK, and Japan. Build. Environ. 2014, 72, 243-258. [CrossRef]

14. Mcgranahan, G.; Balk, D.; Anderson, B. The rising tide: Assessing the risks of climate change and human settlements in low elevation coastal zones. Environ. Urban. 2007, 19, 17-37. [CrossRef]

15. Wang, X.; Zhao, G.; He, C.; Wang, X.; Peng, W. Low-carbon neighborhood planning technology and indicator system. Renew. Sustain. Energy Rev. 2016, 57, 1066-1076. [CrossRef]

16. Xie, Z.; Gao, X.; Feng, C.; He, J. Study on the evaluation system of urban low carbon communities in Guangdong province. Ecol. Indic. 2017, 74, 500-515. [CrossRef]

17. Luo, Q.L.; Zhan, Q.M. Best practice in low-carbon community planning. Adv. Mater. Res. 2012, 450-451, 1082-1085. [CrossRef]

18. Jiang, X.J.; Guo, Z.J. Foreign low carbon community planning comparative analysis. Adv. Mater. Res. 2011, 233-235, 1897-1900. [CrossRef]

19. Moghadam, S.T.; Lombardi, P. An interactive multi-criteria spatial decision support system for energy retrofitting of building stocks using CommuntiyVIZ to support urban energy planning. Build. Environ. 2019, 163, 106233. [CrossRef]

20. $\mathrm{Wu}, \mathrm{C}$. Indicator system construction and health assessment of wetland ecosystem-taking hongze lake wetland, china as an example. Ecol. Indic. 2020, 112, 106164. [CrossRef]

21. Wu, D.; Ding, H.; Chen, J.; Fan, Y. A delphi approach to develop an evaluation indicator system for the national food safety standards of china. Food Control 2020, 121, 107591. [CrossRef]

22. Yuan, W.; James, P.; Hodgson, K.; Hutchinson, S.M.; Shi, C. Development of sustainability indicators by communities in China: A case study of Chongming County, Shanghai. J. Environ. Manag. 2003, 68, 253-261. [CrossRef]

23. Spangenberg, J.H. Environmental space and the prism of sustainability: Frameworks for indicators measuring sustainable development. Ecol. Indic. 2002, 2, 295-309. [CrossRef]

24. Lu, Y.; Wang, R.; Zhang, Y.; Su, H.; Wang, P.; Jenkins, A. Ecosystem health towards sustainability. Ecosyst. Health Sustain. 2016, 1, 1-15. [CrossRef]

25. Marique, A.; Reiter, S. A simplified framework to assess the feasibility of zero-energy at the neighbourhood/community scale. Energy Build. 2014, 82, 114-122. [CrossRef]

26. Han, Y.; Dai, L.M.; Zhao, X.F.; Wu, Y. Construction and application of an assessment index system for evaluating the ecocommunity's sustainability. J. For. Res. 2008, 19, 154-158. [CrossRef]

27. Todd, J.A.; Crawley, D.B.; Geissler, S.; Lindsey, G. Comparative assessment of environmental performance tools and the role of the Green Building Challenge. Build. Res. Inf. 2001, 29, 324-335. [CrossRef]

28. Haapio, A.; Viitaniemi, P. A critical review of building environmental assessment tools. Environ. Impact Assess. Rev. 2008, 28, 469-482. [CrossRef]

29. Reed, M.; Fraser, E.D.; Morse, S.; Dougill, A.J. Integrating Methods for Developing Sustainability Indicators to Facilitate Learning and Action. Ecol. Soc. 2005, 10, 1-6. [CrossRef]

30. Alnaser, N.W.; Flanagan, R.; Alnaser, W.E. Model for calculating the sustainable building index (sbi) in the kingdom of bahrain. Energy Build. 2008, 40, 2037-2043. [CrossRef]

31. Englman, A.Y. A square-root method for the density matrix and its applications to lindblad operators. Phys. A Stat. Mech. Its Appl. 2006, 371, 368-386.

32. Ma, N.; Zhao, Z. Analysis of determining weight coefficient based on AHP and its improvement. Water Conserv. Sci. Technol. Econ. 2006, 11, 732-733.

33. Das, R.; Ball, A.K.; Roy, S.S. Optimization of E-jet Based Micro Manufacturing Process Using Grey Relation Analysis. Mater. Today Proc. 2018, 5, 200-206. [CrossRef]

34. Xia, X.; Sun, Y.; Wu, K.; Jiang, Q. Optimization of a straw ring-die briquetting process combined analytic hierarchy process and grey correlation analysis method. Fuel Process. Technol. 2016, 152, 303-309. [CrossRef]

35. Wang, X.; Peng, G.; Cheng, Y. Fuzzy synthetic evaluation of economic benefit of enterprise based on neural network. In Proceedings of the IEEE International Symposium on Computational Intelligence in Robotics \& Automation, Kobe, Japan, 16-20 July 2003.

36. Wang, J.; Cheng, C.; Huang, K. Fuzzy hierarchical TOPSIS for supplier selection. Appl. Soft Comput. 2009, 9, 377-386. [CrossRef]

37. Jia, J.; Ying, F.; Guo, X. The low carbon development (lcd) levels' evaluation of the world's 47 countries (areas) by combining the fahp with the topsis method. Expert Syst. Appl. 2012, 39, 6628-6640. [CrossRef]

38. Zadeh, L.A. Similarity relations and fuzzy orderings. Inf. Sci. 1971, 3, 177-200. [CrossRef]

39. Lin, J.; Jacoby, J.; Cui, S.; Liu, Y.; Tao, L. A model for developing a target integrated low carbon city indicator system: The case of xiamen, china. Ecol. Indic. 2014, 40, 51-57. [CrossRef]

40. Lou, Y.; Jayantha, W.M.; Shen, L.; Liu, Z.; Shu, T. The application of low-carbon city (lcc) indicators-A comparison between academia and practice. Sustain. Cities Soc. 2019, 51, 101677. [CrossRef] 
41. Middlemiss, L.; Parrish, B.D. Building capacity for low-carbon communities: The role of grassroots initiatives. Energy Policy 2010, 38, 7559-7566. [CrossRef]

42. Heiskanen, E.; Johnson, M.; Robinson, S.; Vadovics, E.; Saastamoinen, M. Low-carbon communities as a context for individual be-havioural change. Energy Policy 2010, 38, 7586-7595. [CrossRef]

43. Zhang, X.; Shen, G.Q.P.; Feng, J.; Wu, Y. Delivering a low-carbon community in china: Technology vs. strategy? Habitat Int. 2013, 37, 130-137. [CrossRef]

44. Zhao, R.; Huang, Y.; Yao, M.X.; Zhan, L.P.; Peng, D.P. Carbon emission assessment of an urban community. Appl. Ecol. Environ. Res. 2019, 17, 13673-13684. [CrossRef]

45. Akbarnezhad, A.; Xiao, J. Estimation and minimization of embodied carbon of buildings: A review. Buildings 2017, 7, 5. [CrossRef]

46. Bellucci, F.; Bogner, J.E.; Sturchio, N.C. Greenhouse gas emissions at the urban scale. Elements 2012, 8, 445-449. [CrossRef]

47. Zhan, G.; Yan, X.; Zhu, S.; Wang, Y. Using hierarchical tree-based regression model to examine university student travel frequency and mode choice patterns in China. Transp. Policy 2016, 45, 55-65. [CrossRef]

48. Chen, J.; Hsieh, H.; Do, Q.H. Evaluating teaching performance based on fuzzy AHP and comprehensive evaluation approach. Appl. Soft Comput. 2016, 28, 100-108. [CrossRef]

49. Feng, S.; Xu, L.D. Decision support for fuzzy comprehensive evaluation of urban development. Fuzzy Sets Syst. 1999, 1051, 1-12. [CrossRef]

50. Wang, J.; Sun, Y. The Application of Multi-Level Fuzzy Comprehensive Evaluation Method in Technical and Economic Evaluation of Distribution Network. In Proceedings of the International Conference on Management and Service Science, Wuhan, China, 24-26 August 2010.

51. Esfahani, S.K.; Karrech, A.; Tenorio, R.; Elchalakani, M. Optimizing the solar energy capture of residential roof design in the southern hemisphere through evolutionary algorithm. Energy Built Environ. 2020, 2, 406-424. [CrossRef]

52. Qin, J.; Hu, E.; Li, X. Solar aided power generation: A review. Energy Built Environ. 2020, 1, 11-26. [CrossRef] 